\title{
OBSERVATIONS ON THE PRESENCE OF RHEUMATOID SERUM FACTOR IN SKIN AND OTHER TISSUES
}

\section{J. BALL}

From the Rheumatism Research Centre, University of Manchester

It has been known for some time that there is an association between rheumatoid serum factor and rheumatoid subcutaneous nodules (Ball, 1950). This suggests that serum factor may be produced in areas of tissue damage, or perhaps be concentrated there. In either case, serum factor might be extractable in greater amounts from the nodules than from either the healthy tissues of the same subject or the non-rheumatoid tissues. This line of reasoning, which initiated the experiments described below, takes no account of immunofluorescent microscopic studies of the localization of rheumatoid factor because most of the experiments were carried out before those studies had been reported. Immunofluorescent microscopy shows that, in the subcutaneous nodules, synovial membranes, and lymph nodes of rheumatoid subjects, serum factor occurs almost exclusively in plasma cells; and it has been suggested that serum factor is synthesized by these cells (Mellors, Heimer, Corcos, and Korngold, 1959; Mellors, Nowoslawski, and Korngold, 1961).

The experiments reported here, concerned as they are with the extraction of serum factor from various tissues, constitute a different approach to this problem of the source of rheumatoid serum factor; the findings indicate that skin contains significant amounts of serum factor and might be an additional site of synthesis of this protein.

\section{Material and Methods}

\section{Material}

Rheumatoid Subcutaneous Nodules.-Specimens were obtained by biopsy from seven subjects, each of whom provided material for a separate experiment.

Skin.-Macroscopically healthy skin was removed from the lower limbs of two subjects with rheumatoid arthritis and one subject with ankylosing spondylitis, the material being taken from an amputated limb in one and at necropsy in the other two. Similar specimens were $N$ removed from the thigh of a limb amputated because of $\mathrm{O}$ diabetic gangrene of the foot and from the limb of $a-$ patient who had died of malignant neuroblastoma. In $\odot$ addition the skin over a rheumatoid subcutaneous $\frac{\mathbb{D}}{O}$ nodule at the elbow was extracted. Each subject provided $\mathbb{\Phi}$ material for a separate experiment.

Articular Soft Tissue.-Joint capsule, synovium, and intra-articular fibrous tissue were obtained at operation $\overrightarrow{0}$ from three patients with rheumatoid arthritis. Three separate extractions were made.

Healthy Fascia.-A specimen was removed from the thigh of a patient who had died of malignant hyper- $\bar{\partial}$ tension.

Diseased Palmar Fascia.-A specimen was obtained from a non $\cdot$ rheumatoid subject undergoing operation for $\overrightarrow{\bar{O}}$ excision of the palmar fascia because of Dupuytren's 3 contracture.

Tendon.-Macroscopically healthy tendon was taken-from the amputated limb of the rheumatoid arthritic who provided one of the skin samples, and from the patient, mentioned above, who died of malignant neuroblastoma.

Liver.-Specimens showing no macroscopic lesion were obtained at necropsy from two of the arthritico subjects from whom skin samples had been taken.

\section{Methods}

The specimen was frozen in liquid nitrogen in a steeliv cylinder and crushed to a fine powder by hammer blows on a solid steel piston which fitted into the cylinder. The powder was transferred to a beaker and weighed. All subsequent manipulations were carried out in a cold roomo at $4^{\circ} \mathrm{C}$. In the case of biopsies, extraction was started $\frac{}{\circ}$ an hour or so after operation. Buffered-saline (an aqueous solution containing $0.2 \mathrm{M} \mathrm{NaCl}$ and $0.01 \mathrm{M}_{\text {T }}$ versene, adjusted to $\mathrm{pH} 7.6$ with $\mathrm{HCl}$ ) was added to theo 
weighed tissue powder in a volume in ml. equivalent to three times the g. weight of the powder. The suspension was allowed to stand with occasional stirring for 2 to 4 hours; it was then centrifuged and the supernatant removed and stored. To the residue, buffered-saline was added in the same volume as before, and the suspension was allowed to stand with occasional stirring for about 18 hours, when it was centrifuged and the supernatant removed and stored. This 18-hours extraction was repeated until a total of four or six supernatants (saline extracts) had been collected. The saline extracts were treated in two different ways as follows.

Method 1 (used in Experiments 1, 2, and 3).-Fourfifths of each saline extract was dialysed for 48 hours against distilled water. The dialysis bag and contents were then dialysed against saline $(0.9$ per cent. $\mathrm{NaCl}$ in water) for 48 hours. Any precipitate formed at this stage was removed by centrifugation; in one experiment the precipitate was shown to contain hydroxyproline and was therefore assumed to be saline-soluble collagen. The supernatant was then dialysed against distilled water to precipitate euglobulin which was taken up in $2 \mathrm{ml}$. saline. The four or six euglobulin solutions were called Extracts 1 to 6 respectively. $0.5 \mathrm{ml}$. of each extract and doubling dilutions thereof were added to an equal volume of sheep cells sensitized by rabbit haemolysin diluted to contain one-half the minimal agglutinating dose. These sensitized sheep cells were about four times as sensitive as those used in the routine diagnostic test. After incubation at $37^{\circ} \mathrm{C}$. for one hour and a further 18 hours at $4^{\circ} \mathrm{C}$., the results were read with the naked eye, the titre being expressed as the reciprocal of the highest dilution causing agglutination. Controls to exclude spontaneous agglutination were set up. In Experiments 1 and 2 the extracts were neither inactivated nor absorbed on normal sheep cells before testing; in Experiment 3 the extracts were absorbed with normal sheep cells before testing and were subsequently shown to be incapable of agglutinating normal sheep cells.

When a sample of rheumatoid serum of known agglutinating activity was put through the extraction procedure, a four-fold reduction in titre occurred; furthermore, in Experiment 1 (see Results), the early saline extracts were inhibitory to rheumatoid serum factor. Both difficulties were thought to be related to the repeated dialysis of the extracts and their concentration by euglobulin precipitation. In subsequent experiments, therefore, the Method 2 was used.

Method 2 (used in Experiments 4 to 13). - In all experiments except No. 13, six serial buffered-saline extracts were obtained and called saline extract 1 to 6 respectively. One half of each extract was used to form an 'extractpool'. Each saline extract and the extract-pool were absorbed on normal sheep cells and then tested for agglutinating activity against sensitized sheep cells as in Method 1. Six serial saline extractions were found to be sufficient to remove all or all but traces of agglutinating activity from the tissue sample.

In all except Experiments 6, 7, and 8, the patient's blood serum was tested for rheumatoid serum factor with the sensitized sheep cells used to test the extracts, the titre being referred to as the patient's "observed serum titre". The haemoglobin content of the extract-pool was estimated by the acid haematin method of Goodman, Lewis, and Schuck (1951). The patient's blood haemoglobin on the day of operation or, in one instance, 2 days after removal of a subcutaneous nodule, was noted. In two of the three cases in which tissue was taken at necropsy, blood haemoglobin values obtained respectively 4 and 7 days before death were accepted; in the other case the data was not available. In Experiments $4,6,7$, and 12 , the patient's packed-cell volume had been estimated at the time of the haemoglobin estimation. In the other cases an assumed value has been used in calculating the plasma content of the blood; as it happened the value for the packed-cell volume is not critical, since an error of plus or minus 20 per cent. would not materially alter conclusions based on these estimations.

The plasma concentration of the extract-pool was estimated from the haemoglobin concentration of the pool and the patient's blood haemoglobin and packedcell volume; and from this the intravascular plasma in the tissue sample was estimated by reference to the total volume of fluid used to extract the sample.

The titre of the extract-pool indicates the content of agglutinating factor in the tissue irrespective of the weight of the tissue sample; thus the titres of the several extract-pools are directly comparable.

The patient's "expected serum titre" was calculated by dividing the intravascular plasma content of the tissue into the total volume of extraction fluid and multiplying by the extract-pool titre. This value was considered to represent the agglutination titre which the patient's blood serum should have been in order to account for the extracted serological activity as expressed by the pool titre. If the patient's "observed titre" proved to be less than the "expected serum titre", it could be inferred that the agglutinating activity of the extract-pool was not derived solely from the intravascular plasma in the tissue sample; in individual cases no significance could be attached to "expected serum titres" which were less than five times the "observed serum titre" because of the errors involved in two titre endpoint readings.

The validity of the calculated "expected serum titıe" is subject to the criticism that the packed-cell volume of the blood in the small vessels and capillaries in tissues may be quite different from that in peripheral venous blood. In healthy tissues the packed-cell volume of capillary blood may indeed be greater than blood taken from a large vein; in this case the intravascular blood and plasma content of the tissue would be overestimated; an error in this direction would, however, tend to minimize the difference which the experiments did in fact disclose, and thus would be acceptable. In inflamed tissues, the el1or may be in the opposite sense, in which case the intravascular plasma content may have been underestimated by some unknown factor. However, the more important conclusions of this study relate to apparently healthy tissues. 


\section{Results}

Experiments 1 to 3.-The results of the first three experiments are shown in Table I. Agglutinating activity was found in some of the saline extracts of all three rheumatoid nodules but not in extracts obtained from normal fascia or the palmar fascia of a patient with Dupuytren's contracture which were tested on the same sensitized cells as extracts of one of the nodules. In Experiment 1, the first two saline extracts from a nodule failed to agglutinate the cells, whereas extracts 3,4 , and 5 succeeded. It was subsequently shown (Table II) that saline extracts 1 and 2 contained an inhibitor active against extract 3 , a rheumatoid serum pool used as a positive control in the routine diagnostic test for rheumatoid serum factor, and against the patient's own serum which was also positive in the routine test. The non-agglutinating saline extracts from the non-rheumatoid tissues (Experiment 2) were carefully tested undiluted, and in serial doubling dilutions, against a diluted rheumatoid serum but no trace of inhibitory activity was detected.

In Experiment 3, the excised nodule was divided

TABLE II

AGGLUTINATION AND INHIBITION BY EXTRACTS OF NODULE (Case 1)

\begin{tabular}{|c|c|}
\hline Equal Volumes of & $\begin{array}{l}\text { Agglutination of } \\
\text { Sensitized } \\
\text { Sheep Cells }\end{array}$ \\
\hline $\begin{array}{l}\text { Undiluted Extract } 3+\text { Undiluted Extract } 1 \ldots \\
\text { Undiluted Extract } 3+\text { Saline } \ldots \\
\text { Undiluted Extract } 3+\text { Normal Euglobulin* } \\
\text { Control Rheumatoid Serum }(1: 256)+ \\
\text { Undiluted Extract } 1 \ldots \\
\text { Control Rheumatoid Serum }(1: 256)+\text { Saline } \ldots \\
\text { Case } 1 \text { Serum }(1: 32)+\text { Undiluted Extract } 2 \ldots \\
\text { Case } 1 \text { Serum }(1: 32)+\text { Saline } \ldots\end{array}$ & $\begin{array}{l}\overline{+} \\
+ \\
\overline{+} \\
\overline{+}\end{array}$ \\
\hline
\end{tabular}

* Diluted to the same volume as the serum from which the euglobulin was derived. into three parts. The ellipse of skin covering the nodule was first removed and any areas resembling fibrinoid dissected away. The vascular fibrous tissue surrounding the nodule and separating the palpably firm fibrinoid areas was separated by sharp dissection. From the residue the macroscopically yellowish foci of fibrinoid (which microscopically appeared avascular and included parts of the palisade border) were dissected out. The skin, fibrous tissue, and fibrinoid were separately extracted and tested on the same cells. The results were surprising in two respects: weight for weight, there appeared to be more rheumatoid factor in the avascular fibrinoid fragments than in the vascular fibrous tissue; secondly, rheumatoid (agglutinating) serum factor appeared to be present in the macroscopically healthy skin covering the nodule.

Experiments 4 to 13.-As explained above (see Methods) an attempt was made in this series of experiments to estimate the intravascular blood content of the extracted tissues.

The agglutinating titre of the six individual extracts and the extract pool are shown in Table III for the skin, articular tissues, and Achilles tendon

TABLE III

AGGLUTINATION OF SENSITIZED SHEEP CELLS BY TISSU EXTRACTS OF A RHEUMATOID ARTHRITIC (Case 4)

(Experiment 4)

\begin{tabular}{c|r|c|c}
\hline \multirow{2}{*}{ Extract } & \multicolumn{3}{|c}{ Titre } \\
\cline { 2 - 4 } & Skin & Articular Tissue & Achilles Tendon \\
\hline 1 & 32 & 16 & 32 \\
2 & 32 & 8 & 16 \\
3 & 8 & 8 & 4 \\
4 & 4 & 4 & 4 \\
5 & 8 & 4 & 4 \\
6 & $<2$ & $<2$ & $<2$ \\
\hline $1-6$ POOL & 8 & 8 & 4 \\
\hline
\end{tabular}

TABLE I

SEROLOGICAL ACTIVITY OF "EUGLOBULIN" FRACTION OF SALINE EXTRACTS

\begin{tabular}{|c|c|c|c|c|c|c|c|c|c|c|c|}
\hline \multirow{2}{*}{\multicolumn{5}{|c|}{ Type and Origin }} & \multirow{3}{*}{$\begin{array}{c}\begin{array}{c}\text { Weight } \\
\text { (g.) }\end{array} \\
7 \cdot 6\end{array}$} & \multicolumn{6}{|c|}{ Sensitized Sheep Cell Agglutination Titre of Extract } \\
\hline & & & & & & 1 & 2 & 3 & 4 & 5 & 6 \\
\hline \multicolumn{2}{|c|}{ (1) Rheumatoid Nodule (Case 1).. } & $\cdots$ & $\cdots$ & $\cdots$ & & $<2$ & $<2$ & 4 & 4 & 2 & \pm \\
\hline \multirow{3}{*}{ (2) } & Rheumatoid Nodule (Case 2) & . & . & . & $3 \cdot 0$ & 8 & 4 & $<2$ & $<2$ & & \\
\hline & Healthy fascia (non-rheumatoi & su & ct) & . & $13 \cdot 0$ & $<2$ & $<2$ & $<2$ & $<2$ & & \\
\hline & Dupuytren's tissue (non-rheun & ato & subject) & .. & $8 \cdot 0$ & $<2$ & $<2$ & $<2$ & $<2$ & & \\
\hline \multicolumn{5}{|c|}{$\begin{array}{l}\text { (3) Rheumatoid Nodule (Case 3): } \\
\text { (a) Skin over nodule .. } \\
\text { (b) Vascular fibrous tissue of nodule } \\
\text { (c) Avascular fibrinoid of nodule } \ldots\end{array}$} & $\begin{array}{r}2 \cdot 7 \\
13 \cdot 4 \\
8 \cdot 2\end{array}$ & $\begin{array}{r}8 \\
16 \\
32\end{array}$ & $\begin{array}{r}4 \\
4 \\
16\end{array}$ & $\begin{array}{r}<2 \\
<2 \\
4\end{array}$ & $\begin{array}{l}<2 \\
<2 \\
<2\end{array}$ & & \\
\hline
\end{tabular}


removed from the amputated leg of a rheumatoid arthritic (Experiment 4). It will be seen that most of the agglutinating activity was recovered in the first two extracts, but that five extractions were necessary to remove agglutinating activity completely. This pattern was characteristic of all the experiments; and in Table IV, which presents the results of Experiments 4-13, only the titre of the extract-pool is given. No evidence of inhibitory activity was observed in any of this series of experiments.

It will be seen (Table IV, Experiment 4) that the total amount of intravascular plasma extracted from the skin was $0.13 \mathrm{ml}$. This was contained in the $488 \mathrm{ml}$. of extraction fluid of which the extract-pool was a sample. The titre of the extract-pool was 8; hence, at this dilution of the extract-pool, the contained plasma was diluted approximately

$$
1: 30,000\left(\frac{488 \times 8}{0 \cdot 13}\right) \text {. }
$$

This value, the patient's "expected serum titre", has been taken to represent the agglutination titre which the patient's blood needs to reach in order to account for the agglutinating activity of the extract-pool. In fact, in Experiment 4, the patient's titre (referred to as the "observed serum titre") was only 1,024. It seems, therefore, that the agglutinating activity extractable from the skin in Experiment 4 was not derived solely from the intravascular plasma in the tissue. The results for the rheumatoid skin of the patient in Experiment 5 were closely similar to those for Experiment 4; and essentially the same findings were obtained in the skin of the patient in Experiment 6, whose serum, which was unfortunately not tested on the relatively sensitive cells used in these experiments, gave a titre of 16 in the routine diagnostic sheep cell agglutination test. In contrast, the extract-pool of the skin samples from the two non-rheumatoid patients (Table IV; Experiments 7 and 8) had no detectable agglutinating activity, though in each

TABLE IV

SEROLOGICAL ACTIVITY OF POOLED TISSUE EXTRACTS (EXPERIMENTS 4-13) AND PATIENT'S SERUM

\begin{tabular}{|c|c|c|c|c|c|c|c|c|c|c|}
\hline \multirow{2}{*}{$\begin{array}{c}\text { Experi- } \\
\text { ment } \\
\text { No. }\end{array}$} & \multicolumn{3}{|c|}{ Clinical Findings } & \multirow{2}{*}{$\begin{array}{l}\text { Tissue } \\
\text { Type }\end{array}$} & \multirow{2}{*}{$\begin{array}{c}\text { Tissue } \\
\text { Weight } \\
\text { (g.) }\end{array}$} & \multirow{2}{*}{$\begin{array}{c}\text { Tissue } \\
\text { Intra- } \\
\text { vascular } \\
\text { Plasma } \\
\text { (ml.) }\end{array}$} & \multirow{2}{*}{$\begin{array}{c}\text { Extrac- } \\
\text { tion Fluid } \\
\text { Volume } \\
\text { (ml.) }\end{array}$} & \multirow{2}{*}{$\begin{array}{c}\text { Extract- } \\
\text { pool } \\
\text { Titre }\end{array}$} & \multicolumn{2}{|c|}{ Patient's Serum Titre } \\
\hline & Diagnosis & $\begin{array}{c}\text { Hb } \\
\text { (g. per cent.) }\end{array}$ & $\begin{array}{c}\text { Packed-cell } \\
\text { Volume } \\
\text { (g. per cent.) }\end{array}$ & & & & & & Expected & Observed \\
\hline 4 & $\begin{array}{l}\text { Rheumatoid } \\
\text { arthritis }\end{array}$ & $10 \cdot 1$ & 34 & $\begin{array}{l}\text { Skin } \\
\text { Joint } \\
\text { Tendon }\end{array}$ & $\begin{array}{l}27 \cdot 1 \\
36 \cdot 1 \\
10 \cdot 2\end{array}$ & $\begin{array}{l}0 \cdot 13 \\
0 \cdot 21 \\
0 \cdot 04\end{array}$ & $\begin{array}{l}488 \\
650 \\
184\end{array}$ & $\begin{array}{l}8 \\
8 \\
4\end{array}$ & $\begin{array}{l}30,030 \\
24,770 \\
18,400\end{array}$ & 1,024 \\
\hline 5 & $\begin{array}{l}\text { Rheumatoid } \\
\text { arthritis }\end{array}$ & $11 \cdot 5$ & $37 \dagger$ & $\begin{array}{l}\text { *Skin } \\
\text { *Liver }\end{array}$ & $\begin{array}{l}11 \cdot 0 \\
34 \cdot 3\end{array}$ & $\begin{array}{l}0 \cdot 07 \\
1 \cdot 79\end{array}$ & $\begin{array}{l}198 \\
617\end{array}$ & $\begin{array}{r}16 \\
4\end{array}$ & $\begin{array}{r}45,260 \\
1,379\end{array}$ & 512 \\
\hline 6 & Spondylitis & $13 \cdot 9$ & 45 & $\begin{array}{l}\text { *Skin } \\
\text { *Liver }\end{array}$ & $\begin{array}{r}5 \cdot 8 \\
15 \cdot 3\end{array}$ & $\begin{array}{l}0.02 \\
0.38\end{array}$ & $\begin{array}{l}105 \\
276\end{array}$ & $\begin{array}{l}4 \\
8\end{array}$ & $\begin{array}{r}21,000 \\
5,811\end{array}$ & - \\
\hline 7 & Diabetes & $10 \cdot 1$ & 33 & Skin & $14 \cdot 0$ & 0.05 & 252 & $<2$ & 一 & $8-16$ \\
\hline 8 & $\begin{array}{l}\text { Neuro- } \\
\text { blastoma }\end{array}$ & - & 一 & $\begin{array}{l}\text { *Skin } \\
\text { *Tendon }\end{array}$ & $\begin{array}{l}8 \cdot 7 \\
3 \cdot 2\end{array}$ & $=$ & $\begin{array}{r}157 \\
58\end{array}$ & $\begin{array}{l}<2 \\
<2\end{array}$ & 二 & - \\
\hline 9 & $\begin{array}{c}\text { Rheumatoid } \\
\text { arthritis }\end{array}$ & $13 \cdot 3$ & $43 \dagger$ & $\begin{array}{l}\text { Joint } \\
\text { Nodule }\end{array}$ & $\begin{array}{r}2 \cdot 2 \\
14 \cdot 8\end{array}$ & $\begin{array}{l}0 \cdot 03 \\
0 \cdot 20\end{array}$ & $\begin{array}{r}39 \\
264\end{array}$ & $\begin{array}{l}64 \\
64\end{array}$ & $\begin{array}{l}83,220 \\
84,480\end{array}$ & 4,096 \\
\hline 10 & $\begin{array}{c}\text { Rheumatoid } \\
\text { arthritis }\end{array}$ & $13 \cdot 9$ & $45 \dagger$ & Nodule & $2 \cdot 6$ & 0.02 & 47 & 4 & 9,401 & 16 \\
\hline 11 & $\begin{array}{c}\text { Rheumatoid } \\
\text { arthritis }\end{array}$ & - & - & Nodule & $0 \cdot 16$ & - & 6 & 16 & - & 512 \\
\hline 12 & $\begin{array}{c}\text { Rheumatoid } \\
\text { arthritis }\end{array}$ & $12 \cdot 1$ & 46 & Nodule & $2 \cdot 2$ & - & 40 & 128 & - & 512 \\
\hline 13 & $\begin{array}{c}\text { Rheumatoid } \\
\text { arthritis }\end{array}$ & $9 \cdot 9$ & $34 \dagger$ & Joint & $16 \cdot 0$ & $0 \cdot 19$ & 288 & 8 & 12,130 & 256 \\
\hline
\end{tabular}


case the first saline extract agglutinated the cells in low titre.

In the three experiments with articular tissue (Experiments 4, 9, and 13), the extract-pools all had agglutinating activity, and in each the "observed titre" was much less than the "expected titre". The extract-pool titre in Experiment 9 was appreciably greater than that in Experiment 4. This may have been related to differences in the tissue which in Experiment 4 consisted largely of rather dense fibrous tissue from the capsule and intra-articular adhesions, whereas in Experiment 9 the tissue sample was hypertrophied synovium typical of chronic rheumatoid arthritis.

Nodules were extracted in Experiments 9, 10, 11, and 12 (Table IV). All the extract-pools agglutinated the cells, though in varying degree; and, as with the skin, tendon, and articular tissue of rheumatoid subjects, the "expected titre" was greatly in excess of the "observed titre" (Experiments 9 and 10). In Experiments 11 and 12 the "expected titre" could not be calculated, but it can be shown that the agglutinating activity of the extract-pool is inexplicable even if it be assumed that the intravascular plasma content of the nodule was equal to the weight of the tissue.

It will be seen (Table IV, Experiment 5) that the liver extract-pool had agglutinating activity; but, unlike the extracts of other rheumatoid tissues, the activity may have been entirely due to the intravascular plasma in the liver because the "expected titre" was only two to three times the "observed titre"; yet skin from the same patient yielded an "expected titre" some 90 times the "observed titre". A similar discrepancy between the skin and the liver extracts was found in Experiment 6.

Subcutaneous nodules tended to yield extracts with higher titres than those observed from articular tissue or skin, the mean $\log _{2}$ titre being 4 to 5,3 , and 2 respectively; these differences, however, are not impressive and the values obtained from these three tissues overlapped. The extract-pool titre tended to rise with the "observed titre" $(r=+0.53)$, but the number of cases was so small that the correlation did not reach statistical significance $(p<0 \cdot 10)$. No relationship was noted between the titre of the extract-pool and the intravascular plasma content of the tissues.

\section{Discussion}

One of the weaknesses of these experiments is, of course, the imprecise characterization of the serologically-active component in the extracts. It has not been shown, for instance, that the sensitized sheep cells were agglutinated by a macrogamma- globulin having a sedimentation coefficient of 19S. $气$ However, the agglutinating activity of rheumatoid $\square$ serum regularly appears in the euglobulin fraction; and the precipitate obtained by dialysis of the $\overrightarrow{\vec{F}}$ extracts against water also contained agglutinating activity. Secondly, the inhibitor detected in Experiment 1 reacted with the agglutinating extracts and $\frac{\bar{\sigma}}{\frac{5}{}}$ with human serum known to contain rheumatoid $\vec{\nabla}$ factor. Thirdly, the possibility that some cellular 2 or intercellular component common to various कs forms of rheumatoid and non-rheumatoid colla- $\overrightarrow{0}$ genous tissues was responsible for agglutination $\vec{\overrightarrow{ }}$ seems improbable because of the absence of agglu- $\vec{\omega}$ tinating activity in the individual extracts or pooled extracts of connective tissue derived from non- $\stackrel{0}{a}$ rheumatoid subjects.

The inconstant occurrence of the agglutination- $i$ inhibitor in euglobulin fractions of saline extracts remains unexplained. Quantitative factors may be 0 partly responsible since the inhibitory activity of saline extracts of various human viscera described $\vec{D}$ by Gray (1959) depended on the protein concen- $\frac{\mathbb{D}}{0}$ tration of the extract. All the extracts may be $\mathbb{\mathbb { D }}$ assumed to have contained some F.II gamma globulin and $\alpha_{2}$ globulin, both of which have been shown $\stackrel{\mathbb{Q}}{-}$ to inhibit rheumatoid serum factor in certais $\overrightarrow{0}$ circumstances, the former when aggregated and tre latter when isolated from whole serum; but accos ding to Franklin (1960) neither appears to play important role in agglutination reactions between whole serum and sensitized sheep cells. When, in $\overline{0}$ the present experiments, no attempt was made to $\circ$ concentrate or fractionate the extracts, no inhibitory $\varrho$ activity was encountered.

Assuming that the serological activity of the extracts was due solely to rheumatoid factor, then it seems that in rheumatoid arthritis rheumatoid factor is present in apparently healthy skin and $\frac{2}{2}$ tendon as well as in pathological tissue such as joint capsules and subcutaneous nodules. In contrast, $\underline{3}$. rheumatoid factor was not detectable in extracts of the skin, fascia, or tendons of non-rheumatoid 3 subjects. No particular significance need be attached 0 to these findings if it could be shown that the activity? of the extracts simply reflects the blood contento of the tissue samples. However, even allowing for gross errors in the estimation of the tissue blood, $\sigma$ it is clear that this is not the case as regards the skin, $N$ tendons, and nodules. (It should perhaps be noted N that the estimated intravascular blood plasma ${ }_{\sigma}^{\omega}$ content of the samples of rheumatoid skin approximate closely to values for the intravascular blood plasma content of rabbit skin reported by Humphrey, Neuberger, and Perkins, 1957.) But, by the same criteria, the agglutinating activity of extracts of the 
liver of rheumatoid subjects was largely or entirely accounted for by the blood in the tissue sample.

It is possible that the agglutinating activity of the extracts depended entirely on the intravascular plasma plus rheumatoid factor adsorbed on to the walls of blood vessels (Hess and Ziff, 1961). If so, the most vascular tissue should have provided the most active extracts. Judged by the estimated blood content, the liver was the most vascular tissue extracted, yet the liver extracts were among the less active. Furthermore, in the one experiment in which the vascular tissues and the avascular fibrinoid foci of the same nodule were compared, the activity of the extracts (on a tissue wet weight basis) was found to be greater in the avascular moiety. Thus, the present experiments point rather strongly to the conclusion that, in subjects with rheumatoid arthritis, appreciable quantities of rheumatoid factor occur in the extravascular compartment of the healthy skin and of certain pathological tissues, whereas this compartment of the liver contains relatively small amounts or none at all; and, in at least some non-rheumatoid subjects, detectable amounts of rheumatoid factor do not occur in the skin or tendon.

Some blood plasma proteins are known to seep into the tissue fluids (Humphrey and others, 1957), but if this mechanism explains the occurrence of extravascular rheumatoid factor, it is difficult to understand why rheumatoid factor was not detected in tissue spaces of the liver. There is some evidence that rheumatoid serum factor does not pass through either the capillary walls of the choroid plexus (Starnes, Ulloa, and Holley, 1961) or the placenta (Den Oudsten, Loghem-Langereis, and Dorfmeijer, 1958; Valkenburg and Mos, 1959). According to Starnes and others (1961), the urine of some patients with rheumatoid arthritis may, when concentrated some 250 times, give a positive result with the slide latex test. The significance of this observation remains uncertain, as the nature of the agglutinating substance was not discovered; however, it was shown that the urine concentrates did not contain detectable 19S gamma globulin. If the reasonable assumption is made that the small blood vessels of the morphologically healthy skin of rheumatoid subjects are not abnormally permeable, it may be inferred that rheumatoid factor occurs in the extravascular compartment of this tissue because it is made there. This conclusion is obviously not permissible as regards inflamed sites such as nodules or articular tissues. All that can be said of these tissues is that extracts of them tend to be more active serologically than skin, but not strikingly so.

At first sight there seems to be little or no common ground between the evidence of the present experiments (which have yet to be confirmed by other workers) and that derived by fluorescent microscopy. According to Mellors and others $(1959,1961)$, rheumatoid factor, as detected by fluorescent aggregated F.II gamma globulin or soluble antigenrabbit antibody complexes, is virtually confined to the plasma cells in synovium and to the germinal centre cells and plasma cells in lymph nodes; the normal skin of rheumatoid arthritics is said not to contain it, and neither do the necrotic centres nor the palisade layer of fibrinoid foci. But rheumatoid factor, as identified by a reaction with sensitized sheep cells, was extractable from both skin and fibrinoid foci. The present observations may be partly reconciled with fluorescent studies if it is assumed that the negative result in rheumatoid skin reported by Mellors and others (1959) was due to the scarcity or absence of plasma cells in random histological sections of skin, and to the fact that only a proportion of the plasma cells are stained in tissues in which rheumatoid factor is detectable by fluorescent methods. More difficult to reconcile is the finding of rheumatoid factor in extracts of necrotic fibrinoid foci. Possibly rheumatoid factor occurs in this tissue in a bound form which does not react in the experimental conditions obtaining in fluorescent studies.

The absence or relatively low content of rheumatoid factor in the extravascular space of the liver is consonant both with an origin of rheumatoid factor in plasma cells and with recent work indicating that the liver cannot synthesize gamma globulin - except when lymphoid and plasma cells occur as part of a pathological change (Thorbecke and Keuning, 1956; Hochwald, Thorbecke, and Asofsky, 1961); and these cells are not a regular or conspicuous finding in the liver of patients with rheumatoid arthritis (personal observations).

Mellors and his co-workers believe that plasma cells not only contain rheumatoid factor but also synthesize and secrete it. There is no direct evidence for this, but recent electron microscopic studies make it an extremely plausible suggestion (Bernhard and Granboulan, 1960); and Mellors and others have, themselves, shown that rheumatoid serum factor is not taken up by plasma cells in vitro, hence it is unlikely that rheumatoid factor is stored in plasma cells. The present work indicates that skin may be an additional site of synthesis of rheumatoid factor. On this theory, significant amounts of rheumatoid factor might be expected to occur in the serum in the absence of pathological lesions containing numerous plasma cells. In fact, relatively high (diagnostic) serum titres of rheumatoid 
factor have been found in a small proportion of healthy subjects; at least some of these sero-positive normal individuals ultimately develop clinical signs of rheumatoid arthritis, and Ball and Lawrence (1961) have suggested that they may do so with a greater frequency than sero-negative individuals.

The work of Humphreys and others (1957) seems particularly relevant to the present observations. In a detailed immuno-chemical study, they not only showed that the healthy skin of rabbits contains significant quantities of plasma type proteins in addition to those present within the blood vessels, but also adduced evidence suggesting that some of these skin proteins (closely resembling if not identical with plasma proteins) may be synthesized therein. With the reasonable assumption that rheumatoid factor does not normally pass the skin capillary barrier, the present findings with rheumatoid skin are entirely in accord with this suggestion.

\section{Summary}

Buffered-saline (pH 7-4) extracts of subcutaneous nodules, joint capsules, liver, healthy skin, and tendon obtained from subjects with rheumatoid arthritis agglutinated sensitized sheep cells; similar extracts from the skin and tendon of non-arthritic subjects did not.

The blood content of the tissue samples accounted for all or most of the agglutinating activity of liver extracts but not of extracts of the other tissues.

It was concluded that significant amounts of rheumatoid serum factor are present in the extravascular compartment of all the extracted rheumatoid tissues, except liver; and it is tentatively suggested that skin may be an important site of synthesis of rheumatoid serum factor.

I wish to record my thanks to Dr. A. H. Gowenlock who carried out the haemoglobin estimations, to Mr. R. Finnigan for technical assistance, and to Professor J. $\mathbf{H}$. Kellgren for reading and criticizing the manuscript. I am also indebted to Dr. D. S. Jackson, who advised on the extraction procedure.

\section{REFERENCES}

Ball, J. (1950). Lancet, 2, 520. and Lawrence, J. S. (1961). Ann. rheum. Dis., $20,235$.

Bernhard, W., and Granboulan, N. (1960). In "Ciba Foundation Symposium on Cellular Aspects of Immunity", p. 92. Churchill, London.

Den Oudsten, S. A., Loghem-Langereis, P. E. van, and Dorfmeijer, H. (1958). Vox Sang. (Basel), n.s. 3, 192.
Franklin, E. C. (1960). Arthr. and Rheum., 3, 314.

Goodman, R. D., Lewis, A. E., and Schuck, E. A. (1951).므. J. Lab. clin. Med., 38, 286.

Gray, J. D. (1959). J. Immunol., 83, 1.

Hess, E., and Ziff, M. (1961). Arthr. and Rheum., 4, 574.

Hochwald, G. M., Thorbecke, G. J., and Asofsky, R. $\frac{\overline{\bar{D}}}{\overline{\mathrm{D}}}$ (1961). J. exp. Med., 114, 459.

Humphrey, J. H., Neuberger, A., and Perkins, D. J.

(1957). Biochem. J., 66, 390.
Mellors, R. C., Heimer, R., Corcos, J., and Korngold, L. (1959). J. exp. Med., 110, 875.

—, Nowoslawski, A., and Korngold, L. (1961). Amer. J. Path., 39, 533.

Starnes, W. R., Ulloa, A., and Holley, H. L. (1961). Arthr. and Rheum., 4, 364.

Thorbecke, G. J., and Keuning, F. J. (1956). J. infect. in Dis., 98, 157.

Valkenburg, H. A., and Mos, A. M. de (1959). Ned. T. Geneesk., 103, 2305.

Observations sur la présence du facteur rhumatismalsérique dans la peau et d'autres tissus

\section{RÉSUMÉ}

Des extraits salins tamponnés $(\mathrm{pH} 7,4)$ de nodules souscutanés, capsules articulaires, foie, peau saine et tendons, provenant de sujets atteints d'arthrite rhumatismale, agglutinaient les globules sensibilisés de moutọ ; $\vec{\bullet}$ des extraits similaires, cutanés et tendineux, des sujęs non-arthritiques ne le faisaient pas.

Le contenu sanguin des prélèvements expliquầt l'action agglutinante partielle ou totale du foie, maiss non pas celle des extraits des autres tissus.

On conclut que d'appréciables quantités de facteuro rhumatismal sérique sont présentes dans la partie extra-0 vasculaire de tous les tissus rhumatismaux prélévés, sauf̊̊̊. dans le foie; on suggère tentativement que la peau peut $\Rightarrow$ être un site important de synthèse du facteur rhumatismalo sérique.

Observaciones sobre la presencia del factor reumatoide sérico en la piel y otros tejidos

\section{SUMARIO}

Extractos salinos tamponados (pH 7,4) de nódulosi subcutáneos, capsulas articulares, hígado, piel normal $\mathrm{y}$ tendones obtenidos de sujetos con artritis reumatoide aglutinaron eritrocitos sensibilizados de carnero; extrac윽 tos similares de la piel y tendon de no-artríticos no los hicieron.

El contenido en sangre de las muestras de tejidos explicó en toda o en mayor parte la acción aglutinanteల్ de los extractos de hígado, pero no la de otros tejidos.

Se concluye que cantitades significantes de factor 0 reumatoide sérico están presentes en las partes extra-N̦ vasculares de todos los tejidos reumatoides extraidos, $\omega$ excepto higado, y se sugiere tentativamente que la piejo puede ser un lugar importante de síntesis del factoro reumatoide sérico. 